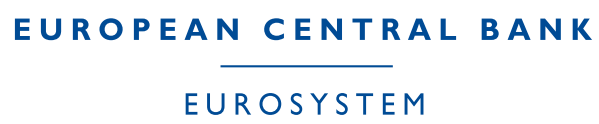

\title{
THE ECB AND THE INTERBANK MARKET
}

Domenico Giannone, Michele Lenza, Huw Pill and Lucrezia Reichlin

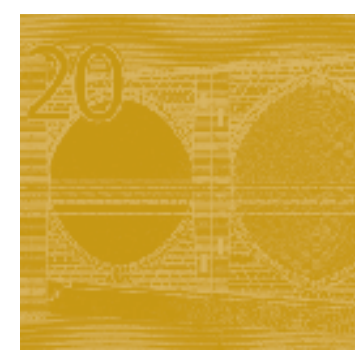

\author{
Huw Pill and Lucrezia Reichlin
}

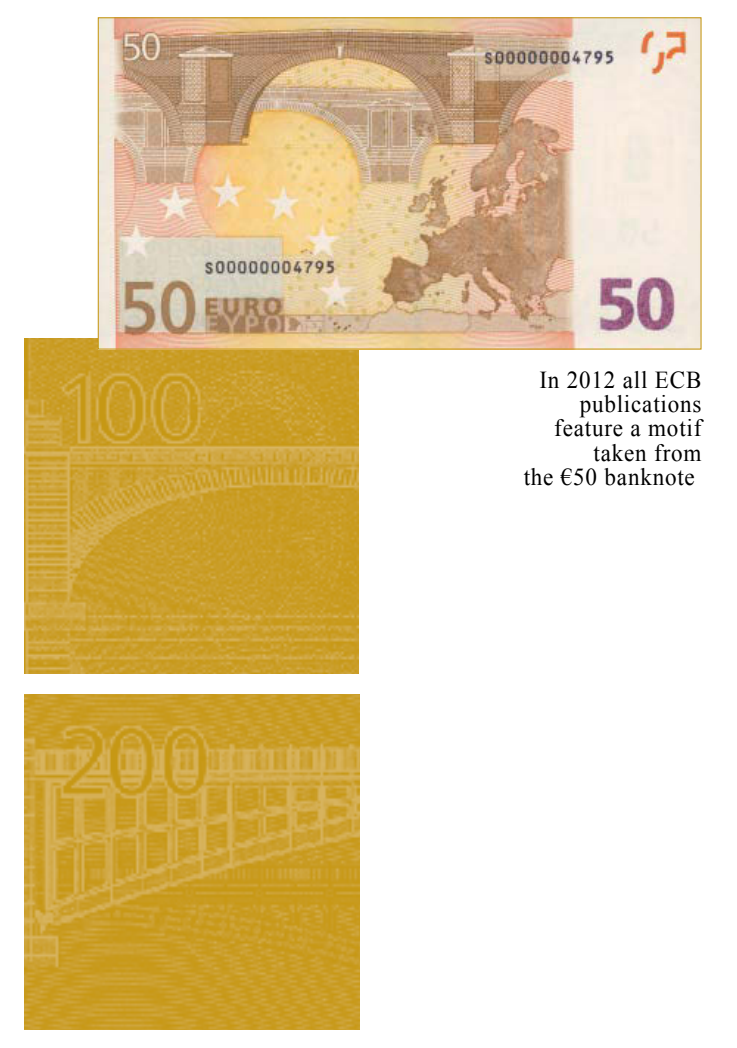

NOTE: This Working Paper should not be reported as representing the views of the European Central Bank (ECB). The views expressed are those of the authors and do not necessarily reflect those of the ECB. 


\section{Acknowledgements}

This paper was prepared for the Bank of England conference ‘Quantitative easing and other unconventional monetary policies' held in London on 18 November 2011. Thanks are due to our discussants, Hashem Pesaran and Michael Wickens, to the conference participants and many current and former colleagues at the ECB for helpful comments. The views expressed in this paper are those of the authors and do not necessarily reflect the views of the ECB or the Eurosystem or Goldman Sachs.

\section{Domenico Giannone}

at Université Libre de Bruxelles - European Center for Advanced Research in Economics and Statistics (ECARES) and Centre for Economic Policy Research (CEPR); e-mail: dgiannon@ulb.ac.be

Michele Lenza

at European Central Bank; e-mail: michele.lenza@ecb.europa.eu

\section{Huw Pill}

at Goldman Sachs; e-mail: huw.pill@gs.com

\section{Lucrezia Reichlin}

at London Business School and Centre for Economic Policy Research (CEPR); e-mail: lreichlin@london.edu

(C) European Central Bank, 2012

\section{Address}

Kaiserstrasse 29, 60311 Frankfurt am Main, Germany

Postal address

Postfach 1603 19, 60066 Frankfurt am Main, Germany

\section{Telephone}

+496913440

\section{Internet}

http://www.ecb.europa.eu

\section{Fax}

+496913446000

All rights reserved.

ISSN 1725-2806 (online)

Any reproduction, publication and reprint in the form of a different publication, whether printed or produced electronically, in whole or in part, is permitted only with the explicit written authorisation of the ECB or the authors.

This paper can be downloaded without charge from http://www.ecb.europa.eu or from the Social Science Research Network electronic library at http://ssrn.com/abstract_id=2178378.

Information on all of the papers published in the ECB Working Paper Series can be found on the ECB's website, http://www.ech.europa.eu/pub/scientific/wps/date/html/index.en.html 


\begin{abstract}
We analyse the impact on the euro area economy of the ECB's non-standard monetary policy measures by studying the effect of the expansion of intermediation of interbank transactions across the central bank balance sheet. We exploit data drawn from the aggregated Monetary and Financial Institutions (MFI) balance sheet, which allows us to construct a measure of the 'policy shock' represented by the ECB's increasing role as a financial intermediary. We find small but significant effects both on loans and real economic activity.
\end{abstract}

Keywords: Non-standard monetary policy measures, interbank market

JEL codes: E5, E58 


\section{Non-technical summary}

This paper analyses the macroeconomic impact of the European Central Bank (ECB)'s non-standard policy measures implemented in the aftermath of the collapse of Lehman Brothers in the autumn of 2008.

Following Lehman's bankruptcy, owing to its exposure to sub-prime mortgage securities, concerns emerged about the creditworthiness of other banks, including those in the euro area. With banks fearing that their counterparts in the interbank market would default, trading in unsecured markets significantly declined.

The interbank market is central to the entire financial system: in normal times, it is the main venue for banks to obtain short-term financing. The seizing up of the interbank market therefore threatened financial stability more widely and, through its effect on liquidity and credit availability, also macroeconomic performance.

To prevent these malicious effects, the ECB stepped in with a series of measures designed to allow banks to continue to obtain short-term finance even while the money market was dysfunctional.

Two crucial elements of the ECB initiatives in 2008 were: First, to adopt a 'fixed rate / full allotment' tender procedure in its operations, which allowed banks to get access to a potentially unlimited amount of financing from central bank operations at a low and predictable borrowing rate, provided that they post sufficient amounts of eligible collateral; and second, to broaden the collateral eligible for those operations, such that the freezing in some market segments would not lead to a shortage of collateral for Eurosystem operations.

We characterise these measures as facilitating an expansion of the intermediation of bankto-bank transactions across the ECB balance sheets, which could substitute for the normal transactions in the money market that were no longer taking place.

In this paper, we can explore this substitution more directly than in previous work, since we exploit data drawn from the aggregate Monetary and Financial Institutions (MFI) balance sheet. These data allow us to identify both: (a) transactions between banks; and (b) transactions between banks and the ECB. We show that the latter grew following the introduction of non-standard measures, while the former declined. 
We use this analysis to explore the macroeconomic implications of the ECB's measures. We demonstrate that, by ensuring banks maintained access to short-term financing, the measures avoided a collapse of liquidity and credit. In turn, this helped to sustain economic activity.

More specifically, we find that bank loans to households and, in particular, to non-financial corporations are higher than would have been the case without the ECB's intervention.

In turn, the ECB's support has a significant impact on economic activity: according to the analysis presented in this paper, two and a half years after the failure of Lehman Brothers, the level of industrial production is estimated to be $2 \%$ higher, and the unemployment rate 0.6 percentage points lower, than would have been the case in the absence of the ECB's non-standard monetary policy measures.

By avoiding the potential collapse of interbank transactions and thus financial intermediation more generally, the ECB's policy measures therefore played an important role in avoiding an even worse macroeconomic outturn in the euro area following the failure of Lehman Brothers. 


\section{Introduction}

In meeting the challenges posed by the on-going financial crisis, the world's leading central banks have resorted to a variety of unconventional monetary policy measures, largely revolving around changing the size and composition of their own balance sheets: 'credit easing' in the United States; 'quantitative easing' in the United Kingdom; and 'enhanced credit support' in the euro area. Such measures are credited by some with having saved the world from another Great Depression. They certainly appear to have played an important role in halting the disorderly collapse that threatened to engulf the global financial system after the failure of Lehman Brothers in September 2008.

Much of the existing analysis of these non-standard monetary policy measures focuses on portfolio balance effects. ${ }^{1}$ As their starting point, these analyses take the view that, owing to financial frictions in credit markets, assets held in private sector portfolios are not perfect substitutes for one another, even once allowing for credit risk and other inherent attributes. In short, where financial markets are not 'efficient' (in the sense of Fama, 1970), changes in the central bank's asset portfolio - which, as a mirror image, imply changes in the private sector balance sheet - can induce changes in the structure of yields and returns. In turn, these changes in asset prices may influence private spending, saving and investment decisions and thus macroeconomic outcomes.

In previous work on the euro area (Lenza et al., 2010; Giannone et al., 2011), we have argued that another channel of transmission for non-standard monetary policy measures may be equally, if not more, important. This alternative view starts from the premise that financial markets can periodically become dysfunctional on account of information problems. The simplest example - but nonetheless arguably that most relevant for analysis of the period immediately following Lehman's demise in September 2008 - concerns a situation where an external shock raises questions about the solvency of some potential counterparties in a financial market. Owing to the inherent asymmetric nature of information regarding the strength of bank balance sheets, adverse selection can occur in that market, leading to some financial institutions being 'red-lined,' i.e. excluded from the market at any price. ${ }^{2}$ Ultimately the private market can simply cease to function. ${ }^{3}$

1 See e.g. section 6.1 of Joyce et al. (2010) for an analysis of the UK experience; the underlying framework is described in Walsh (1982).

See Stiglitz and Weiss (1981).

3 See Heider et al. (2009) for a theoretical model of such phenomena applied to the money market. 
This situation is likely to prove costly for the economy as a whole when potential spillovers to other financial markets are high. Such is the case in the interbank money market, the focus of the present study. The interbank money market plays a central role in refinancing short-term financial positions in the economy. Should the money market freeze, banks and other investors will no longer be able to fund their asset holdings and are likely to be forced to liquidate their positions and call loans prematurely. The resulting asset fire sale can trigger a self-sustaining vicious spiral of eroding collateral value and diminishing liquidity, with systemic consequences for the financial sector and wider macroeconomy. ${ }^{4}$

Central banks therefore have a strong case to intervene should money markets seize up: in doing so, they aim at insulating the broader economy and financial system from the impact of the breakdown of liquidity and activity in a specific segment of the financial markets. The simplest way for the central bank to undertake such intervention is to expand intermediation across its own balance sheet, so as to substitute for the private transactions that no longer take place in the dysfunctional market segment. ${ }^{5}$ Expansion of central bank intermediation and its implications for macroeconomic and financial aggregates are the topics that we explore in this paper.

The novelty of the exercise compared to our earlier work is that we include interbank positions in our analysis, rather than netting them out through consolidation. Crucially, we are able to distinguish between banks' positions with other commercial banks and their positions with the Eurosystem. ${ }^{6,7}$ This innovation relies on our use of a rich, but previously under-exploited, data base: the aggregated balance sheet of euro area monetary and financial institutions (MFIs). It allows us to analyse the impact of substitution between private activity in the interbank money market and central bank intermediation of bank-tobank transactions, which lies at the heart of our interpretation of the ECB's non-standard monetary policy measures. In particular, we focus attention more directly on the evolution of quantities most immediately affected by non-standard policy measures, rather than relying on the evolution of interest rate spreads as indirect proxies of their effects as we have done in previous work. Our sample ends in April 2011, and therefore excludes the

\footnotetext{
See Brunnermeier and Pedersen (2009).

For a more general discussion, see Durre and Pill (2012).

For clarity, recall that the Eurosystem consists of the ECB plus the (now) 17 national central banks of those EU countries that have adopted the euro as their currency.

7 Our analysis addresses an issue raised in Chari et al. (2008). They identify as a myth that interbank lending fell during the first phase of the crisis, but do not distinguish between private and central bank intermediation. Here we aim at addressing this shortcoming in their analysis.
} 
new wave of non-standard policy measures (notably the ECB's 3-year LTRO operations) implemented after the summer of 2011.

To anticipate our results, our exercise provides a new measure of the ECB's non-standard monetary policy intervention. This measure reflects an estimate of how changes in the ECB's operational procedures (particularly following the failure of Lehman Brothers) influenced the magnitude of central bank intermediation provided by the Eurosystem. We then analyse the evolution of macroeconomic and financial variables associated with our estimate of the ECB's non-standard policy measures. We find that the ECB intervention is associated with higher bank loans to households and, in particular, to non-financial corporations than would have been the case without it. In turn, the ECB's support is associated with a significant improvement on economic activity: two and a half years after the failure of Lehman Brothers, the level of industrial production is estimated to be $2 \%$ higher, and the unemployment rate 0.6 percentage points lower, than would have been the case in the absence of the ECB's non-standard monetary policy measures.

The remainder of the paper is organised as follows. Section 2 describes the potential role of central bank intermediation in substituting for private money market activity. Section 3 describes the key features of our data set, while Section 4 describes the econometric methodology underlying our modelling of the euro area economy. In Section 5 we describe the main results of our study and in section 6 we discuss some caveats to them, before offering some concluding remarks in Section 7. 


\section{Intra-financial sector financial flows and central bank intermediation}

Over time, euro area banks have become increasingly dependent on wholesale funding (see Figure 1). Rather than relying - as they traditionally had done - on deposits from households and non-financial corporations (NFCs) (our definition of retail funding), euro area banks have placed growing reliance on funding from other parts of the financial sector obtained via the wholesale money market. ${ }^{8}$ This process accelerated as the pace of bank credit expansion picked up in 2004-07. It is not a phenomenon unique to Europe: using U.S. flow of funds data, Adrian and Shin (2010a,b) have shown that other banks represented a significant source of funding, especially for U.S. broker/dealers (investment banks). Much of this financing took the form of repos of securitised assets. Moreover, Adrian and Shin demonstrate that the implied build-up of intra-banking sector leverage was associated with the creation of longer intermediation chains, i.e. the flow of resources from non-bank saver to non-bank borrower passed through an increasing number of banks.

$<$ insert Figure $1>>$

With a shift in composition to wholesale sources, the stock of bank funding became less stable. Households and NFCs could be relied upon to maintain a steady level of deposits through the business cycle, but wholesale funding tends to be more flighty, possibly imparting a pro-cyclical bias to the expansion of financial intermediation. ${ }^{9}$ Moreover, the accumulation of intra-financial sector leverage created a systemic vulnerability: if one institution chooses to shrink its balance sheet, the resulting withdrawal of wholesale funding puts pressure on others to do likewise (and so on). A self-sustaining spiral of forced deleveraging can ensue. Even if this does not necessarily have immediate implications for the flow of bank loans to the household and corporate sectors (after all, interbank positions must net to zero within the banking sector), the loss of market liquidity may prompt non-bank financial institutions to withdraw from the wholesale money market, leading to a broader credit contraction. Indeed, the post-Lehman crisis in the money market has been characterised as a run on wholesale bank funding of this form. ${ }^{10}$

In the face of such a seizing-up of the interbank market, the ECB has stepped in to intermediate the underlying flow of financial resources from savers to borrowers across its

\footnotetext{
8 Using the ECB's statistical definitions, our definition of 'wholesale funding' underlying Figure 1 encompasses deposits placed by: money market funds (MMFs), insurance companies and pension funds (ICPFs), other financial institutions (OFIs); non-residents; and monetary financial institutions (MFIs).

9 See Shin and Shin (2011).

10 See Gorton and Metrick (2012).
} 
own balance sheet. In essence, the ECB's non-standard measures represent an attempt to use various tools available under its operational framework for the implementation of monetary policy to act as a central counterparty for interbank transactions. By so doing, the ECB replaces the frozen private interbank money market at the centre of wholesale bank funding activity and thereby sustains the necessary flow of credit to the real economy. An immediate implication of facilitating financial transactions in this way has been a substantial expansion of the ECB balance sheet.

Allowing greater intermediation across the ECB balance sheet prevented a collapse of the financial sector and mitigated the impact of market turmoil on the real economy. In line with the description of financial intermediation that can be found in any standard banking textbook, the ECB's activities grew along a number of dimensions. ${ }^{11}$

First, maturity transformation performed by the ECB increased significantly. By: (a) increasing the share of liquidity supplied at its long-term refinancing operations (LTROs) relative to its regular main refinancing operations (MROs); and (b) increasing the maturity structure of its LTROs by offering operations out to one-year; the ECB substantially increased the average maturity of its outstanding repos. And since these operations were 'funded' by the accumulation of excess liquidity at the ECB's (overnight maturity) deposit facility, this resulted in substantial maturity transformation, allowing the banking sector to become less reliant on (very) short-term financing and passing at least part of the maturity mis-match inherent in banking activities to the central bank.

Second, the ECB increased its provision of liquidity transformation. In particular, the ECB accepted as collateral in its refinancing operations assets that had become illiquid in financial markets (notably mortgage-backed securities, given the freezing of the private market for securitised instruments). In its operations, the ECB provided cash loans against the security of these assets. The banking sector was therefore able to transform illiquid instruments into cash at relatively low cost, avoiding a need to engage in disorderly 'fire sales' of those assets to raise liquidity. Such fire sales may have led to a self-sustaining downward spiral in asset markets and collateral values, imposing capital losses and liquidity squeezes on the banks themselves. In short, the systemic threat posed by fire sale externalities was contained by central bank action.

11 See Trichet (2009) and Fahr et al. (2010). 
Third, the ECB increased its provision of transactions services and its support to the distribution of liquidity within the financial sector. This was facilitated by the very large number of counterparties eligible for Eurosystem operations, which allowed the central bank to establish itself as a central counterparty (or 'hub') in the complex web of interbank transactions ('spokes'). Participation in Eurosystem operations increased over the course of the crisis as central bank intermediation replaced interbank transactions: at the peak, more than one thousand different counterparties bid at the operations.

Finally, the ECB's measures addressed the adverse selection problems (created by a perceived deterioration in counterparty credit risk) that were widely seen as underlying the financial crisis. $^{12}$ In particular, the ECB conducted operations in a manner that protected counterparties' anonymity and thus avoided the danger that operations became 'stigmatized'. Of course, this rather benign interpretation of the ECB's measures has to be set against the possibility that rising counterparty risk was not just perceived in an environment of asymmetric information, but real. By acting as a central counterpart, the ECB offered novation services: in other words, it absorbed onto its own balance sheet the credit risks that were preventing the underlying bank-to-bank transaction from taking place in private markets. As argued by Durre and Pill (2010), the ECB's ability to absorb such risk, although substantial, is not infinite. Ultimately, accumulation of credit risk will compromise its ability to pursue its mandate to preserve price stability.

But such concerns about the strength of the ECB balance sheet will only emerge over the medium to longer term. In the remainder of this paper, we focus on shorter-term crisis management. Indeed, in light of subsequent events, it is important to emphasise that the empirical analysis presented below focuses on the period between the collapse of Lehman Brothers (in September 2008) and the onset of the European sovereign debt crisis (in May 2010). By its nature, such a focus is limiting: we do not dispute that many important monetary policy issues arose both in the period of market turmoil before Lehman's demise and later as government debt tensions subsequently intensified. But maintaining this focus allows us to undertake a sharper exercise.

12 e.g., by Heider et al. (2009). 


\section{Data: consolidated and aggregated MFI balance sheets}

Our previous analyses of euro area bank behaviour during the financial crisis have relied on the consolidated MFI balance sheet, which forms the basis for the construction of euro area monetary aggregates. The consolidated balance sheet nets out intra-MFI positions: it captures the flow of deposits from the domestic private sector into the banking system and the flow of bank loans to the domestic private sector, but excludes all the intervening transactions among banks. ${ }^{13}$

Since the essence of our characterisation of the ECB's non-standard measures is that the ECB acts as a central counterparty facilitating transactions that previously took place in the interbank market, this represents a serious shortcoming. While we have been able to estimate the overall reduced-form impact of ECB interventions on macroeconomic and financial variables of interest, we have not provided evidence for the structural and behavioural channels through which these measures have operated.

In this paper, we used data derived from the aggregated MFI balance sheet. This does not net out interbank transactions: rather the flow of loans from one bank to another are summed and included on the asset side, while the counterpart deposits are included on the liability side. Moreover, we are able to distinguish between those inter-MFI flows that reflect transactions between commercial banks and those associated with transactions between commercial banks and central banks. By implication, we can investigate the interactions between direct and central bank intermediation of bank-to-bank transactions.

To offer a preliminary look at the interaction of these variables, Figure 2 shows two measures of the extent of central bank intermediation: (1) the (log) level of outstanding Eurosystem operations with euro area MFIs; and (2) outstanding Eurosystem operations as a percentage of total intra-MFI liabilities. As one would expect, both these measures demonstrate an upward shift as of October 2008, reflecting the ECB's adoption of a fixed rate full allotment tender procedure in its monetary policy operations following the failure of Lehman Brothers. Adopting such a procedure implied that the ECB accommodated banks' demand for central bank intermediation in full, at price conditions determined by the ECB. In other words, there was no rationing of access to central bank intermediation: at the pre-announced price (i.e. the fixed rate at the MROs), the supply of central bank

13 By construction, interbank positions should consolidate to zero: a short-term loan from bank X to bank Y is equivalent to a deposit placed by bank $\mathrm{Y}$ at bank $\mathrm{X}$. 
liquidity and intermediation was perfectly elastic. Given that demand for central bank intermediation was very strong in a context of malfunctioning financial market, borrowing at the ECB's repo operations jumped significantly.

$$
<\text { insert Figure } 2>>
$$

More concretely, from the euro area aggregated MFI balance sheet we construct a monthly data set for the period January 1999 through April 2011 consisting of 26 variables. Our decision to aggregate the underlying much more finely delineated time series available in the MFI data base into these 26 variables reflects a trade-off between, on the one hand, maintaining a tractable econometric model and, on the other hand, having a rich description of bank balance sheet behaviour. Importantly, by including residual items ('other assets' and 'other liabilities') on each side of the balance sheet, we allow for the balance sheet constraint to be imposed during model estimation.

On the asset side, we include MFI loans to the following sectors: MFIs (thereby capturing the intra-MFI position), households, NFCs, insurance companies and pension funds (ICPFs), other financial institutions (OFIs), and government. We break some of these sectorial components into short and long-term maturity buckets. We also include bank holdings of debt securities and equities, as well as 'other assets' as mentioned above. On the liability side, we include deposits held at MFIs by each of the sectors listed above (where we distinguish between inter-bank liabilities and MFI liabilities versus the Eurosystem), plus capital and 'other liabilities'. ${ }^{14}$

The 26 variables constructed using the aggregate MFI balance sheet are complemented with 17 other macro time series, to produce an overall model with 43 variables. Key monthly macro cyclical indicators are: industrial production; unemployment, consumer prices and producer prices. From financial markets, we include: the 3-month Euribor; bond yields at two 2, 5 and 10 years maturities to capture the term structure of interest rates; equity price indices (for the market as a whole and for the banking sector). Finally, we include a number of U.S. variables to capture the external economic environment facing the euro area and bank's lending rates to households (distinguishing between consumer credit and loans for house purchases) and Non-Financial Corporations (distinguishing between long and short term loans). A description of the variables used and the statistical transformations we used in the model is provided in the Appendix.

14 The full database is available from the authors on request. 


\section{Empirical methodology}

\subsection{Model and estimation}

Using the data set described in the previous section, we estimate an empirical model of the euro area economy. Let $\mathbf{x}_{\mathbf{t}}$ be the vector including the $n(=43)$ variables listed in the appendix. We estimate a vector autoregressive $(\mathrm{VAR})$ model with $p(=13)$ lags:

$\mathbf{x}_{t}=\mathbf{A}_{0}+\mathbf{A}_{1} \mathbf{x}_{t-1}+\mathbf{A}_{2} \mathbf{x}_{t-2}+\ldots+\mathbf{A}_{p} \mathbf{x}_{t-p}+\mathbf{e}_{t}$

where $\mathbf{e}_{t}$ is a normally distributed multivariate white noise with covariance matrix $\boldsymbol{\Sigma}$.

The large dimension ( $n=43$ and $p=13)$ of our VAR model implies that we face an issue of over-fitting, owing to the large number of parameters (the so-called "curse of dimensionality"). We address this issue by shrinking the model's coefficients toward those of the naïve and parsimonious random walk with drift model, $x_{i t}=\delta_{i}+x_{i, t-1}+e_{i t}$ De Mol et al. (2008) and Banbura et al. (2010) have shown that this approach reduces estimation uncertainty without introducing substantial bias. This is achieved thanks to the tendency for macroeconomic time series to co-move over the business cycle, which creates scope for the data to point "massively" in the same direction against a naïve prior model that does not allow for any dynamic interaction. The resulting model offers a parsimonious but reliable estimate of the complex dynamic interactions among the macro, monetary and financial variables included in the data set.

More specifically, we use a Normal-Inverted Wishart prior centred on a random walk model. For $\Sigma$, the covariance matrix of the residuals, we use an inverted Wishart with scale parameter given by a diagonal matrix $\Psi$ and $d=n+2$ degrees of freedom. This is the minimum number of degrees of freedom that guarantees the existence of the prior mean of $\boldsymbol{\Sigma}$, which is equal to $\boldsymbol{\Psi} /(\mathrm{d}-\mathrm{n}-1)=\boldsymbol{\Psi}$. For the constant $\mathrm{A}_{0}$ term, we use a flat prior. For the autoregressive coefficients $\left(\mathbf{A}_{1} \ldots \mathbf{A}_{\mathrm{p}}\right)$, we use the Minnesota and the sum of coefficients priors, as originally proposed by Litterman (1980) and Doan et al. (1984) respectively.

As regards the Minnesota prior, conditional on the covariance matrix of the residuals, the prior distribution of the autoregressive coefficients is normal with the following means and variances:

$\mathrm{E}\left(\mathbf{A}_{1}\right)=\mathbf{I}_{\mathrm{n}}$ while $\mathrm{E}\left(\mathbf{A}_{2}\right)=\ldots=\mathrm{E}\left(\mathbf{A}_{\mathrm{p}}\right)=\mathbf{0}_{\mathrm{n}, \mathrm{n}}$

$\operatorname{Cov}\left[\left(\mathbf{A}_{\mathrm{s}}\right)_{\mathrm{ij}}\left(\mathbf{A}_{\mathrm{r}}\right)_{\mathrm{hm}} \mid \Sigma\right]=\lambda^{2} \boldsymbol{\Sigma}_{\mathrm{ih}} /\left(\mathrm{s}^{2} \boldsymbol{\Psi}_{\mathrm{iij}}\right)$ if $\mathrm{m}=\mathrm{j}$ and $\mathrm{r}=\mathrm{s}$, zero otherwise. 
Notice that the variance of this prior distributions decays with the lag, and that coefficients associated with the same variables and lags in different equations are allowed to be correlated. The key hyperparameter is $\lambda$, which controls the scale of all the prior variances and covariances, and effectively determines the overall tightness of this prior. For $\lambda=0$ the posterior equals the prior and the data do not influence the estimates. If $\lambda \rightarrow \infty$, on the other hand, posterior expectations coincide with the Ordinary Least Squares (OLS) estimates. The factor $1 / \mathrm{s}^{2}$ is the rate at which the prior variance decreases with increasing lag length and $\boldsymbol{\Sigma}_{\mathrm{ii}} / \Psi_{\mathrm{ij}}$ accounts for the different scale and variability of the data.

As regards the sum of coefficients priors, which we additionally impose on the autoregressive coefficients, this represents "inexact differencing," i.e. it is a simple modification of the Minnesota prior involving linear combinations of the VAR coefficients. More precisely, rewrite the VAR equation in error correction form:

$\Delta \mathbf{X}_{t}=A_{0}-\left(I_{n}-A_{1}-\cdots-A_{p}\right) \mathbf{X}_{t-1}+B_{1} \Delta \mathbf{X}_{t-1}+\cdots+B_{p-1} \Delta \mathbf{x}_{t-p+1}+e_{t}$.

A VAR in first differences implies the restriction $\left(I_{n}-A_{1}-\cdots-A_{p}\right)=\mathbf{0}$. We follow Doan et al. (1984) and set a prior that shrinks $\boldsymbol{\Pi}=\left(\mathrm{I}_{n}-\mathrm{A}_{1}-\cdots-\mathrm{A}_{\mathrm{p}}\right)$ towards zero. This can be understood as "inexact differencing". In the literature it is usually implemented by adding dummy observations. The tightness of this additional prior is controlled by the hyperparameter $\mu$. As $\mu$ goes to infinity the prior becomes diffuse while, as $\mu$ goes to 0 , we approach the case of exact differencing which implies the presence of a unit root in each equation.

Summing up, the setting of these priors depends on the hyperparameters $\lambda$ and $\mu$, which reflect the informativeness of the prior distribution for the model's coefficients. These parameters are usually set on the basis of subjective considerations or rules of thumb. We follow a more formal approach proposed by Giannone et al. (2012). This involves treating the coefficients of the prior as additional parameters, in the spirit of hierarchical modeling. In this paper we use an improper flat distributions as hyperprior. For simplicity, do we do not account for uncertainty on hyperparameters and set them at their posterior mode. ${ }^{15}$ Given the hyperparameters, the VAR coefficients can then be drawn from their posterior, which is Normal- Inverse-Wishart.

\footnotetext{
${ }^{15}$ Since our hyperpriors are flat, the chosen hyperparameters maximize the marginal likelihood (see Giannone et al., 2012 for details).
} 
In order to assess the ability of the model to capture the interconnections between the banking system and the macroeconomy, we compute the expected path of balance sheet item conditional on the remaining variables of the system. Table 1 below reports a measure of fit defined as one minus the ratio of the residual's variance in the conditional forecast relative to the residual's variance implied by the prior model, which postulates the complete absence of interdependence among all the variables in the system. The fit is quite large, indicating that there is strong comovement between macro and financial series (on this point see also Giannone et al., 2012).

Table 1: The quality of fit of bank balance sheet variables

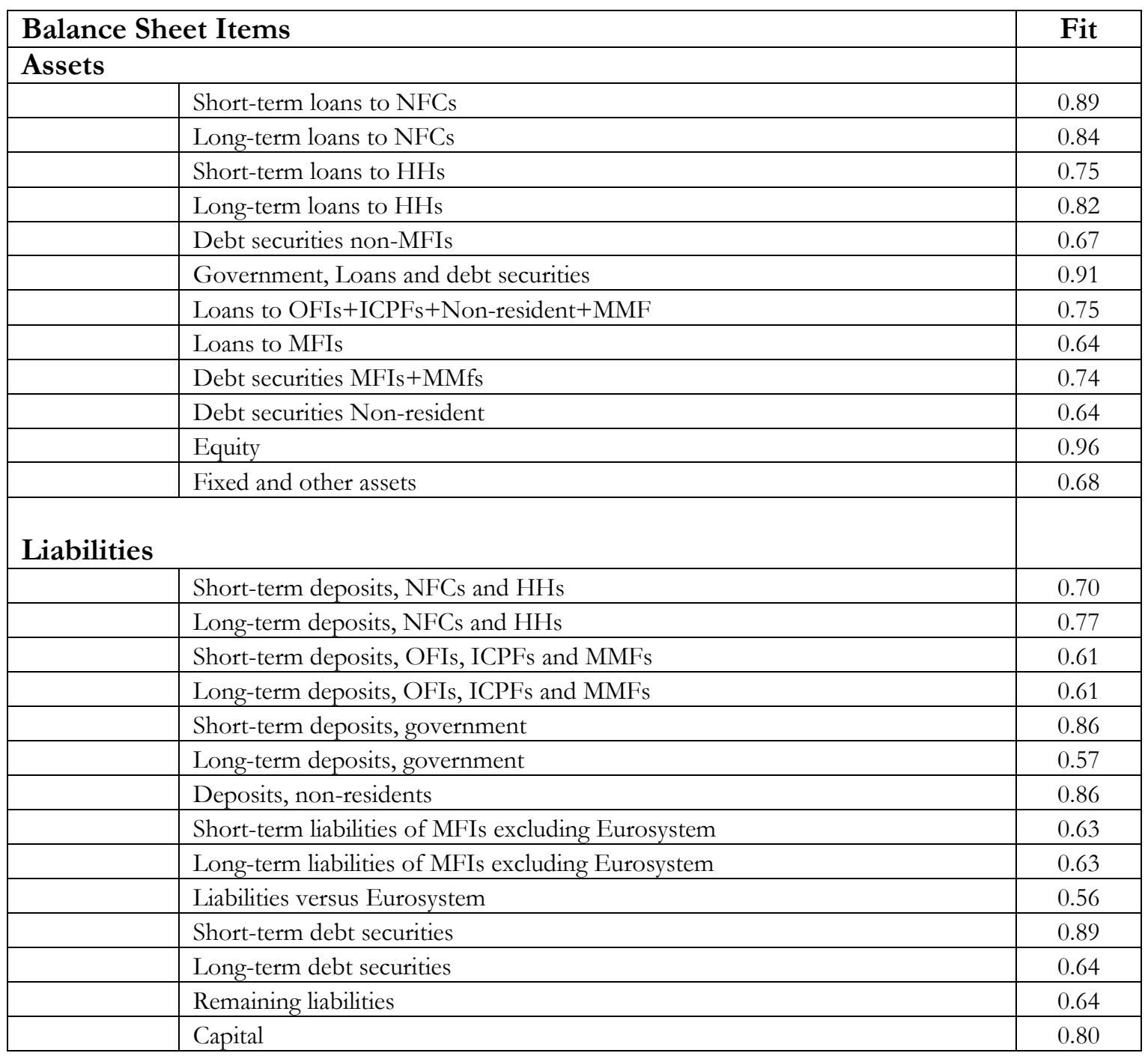

Note: The acronyms in the table are: NFCs (Non-financial corporations), HHs (households), MFIs (Monetary and financial institutions), OFIs (Other financial institutions), ICPFs (Insurance companies and pension funds), MMFs (Money market funds) The sample ranges from January 1999 to April 2011 (monthly data, 148 observations) The conditional forecasts are computed by setting the model's parameters at the posterior mode computed using the entire sample 


\subsection{Counterfactual analysis}

Using the model estimated according to the methods described above, our analysis proceeds in two steps.

\section{Step 1: Estimating the 'size' of non-standard measures}

We first compute the posterior of the parameters using the data until July 2007 since we are interested in conditioning on the statistical regularities or 'stylised facts' inherent in the 'pre-crisis' euro area economy. Given the rich specification of the model in terms of bank balance sheet data, our focus is the monetary and financial characteristics. Second, we set the parameters at their posterior mode and construct a forecast for central bank intermediation (Eurosystem) for the period from August 2007 until April 2011. This forecast is conditional on the actual path of the variables capturing economic activity in the model (i.e. industrial production, unemployment, and U.S. industrial production). Third, we compare this conditional forecast for Eurosystem intermediation with the observed series.

Our interpretation of this exercise is as follows. The conditional forecast reflects the anticipated evolution of the ECB's balance sheet given the observed path of economic activity during the financial crisis, assuming that the historical pre-crisis regularities in the euro area data are maintained. This represents a pre-crisis benchmark capturing the anticipated behaviour of the Eurosystem in the face of a marked fall in economic activity. The observed evolution of Eurosystem intermediation is then compared with this benchmark. The observed path of the ECB balance sheet during the financial crisis is, of course, also conditional on the observed path of economic activity. But, by nature, the observed path is also conditional on the non-standard monetary policy measures introduced by the ECB after the failure of Lehman.

Thus the difference between the conditional forecast and the observed path of Eurosystem intermediation captures the impact of the ECB's policy actions on the evolution of its balance sheet. Therefore we can view this measure as an estimate of the size of the ECB's non-standard policy measures as reflected in quantities on the ECB's balance sheet.

\section{Step 2: Estimating the impact of non-standard measures on the financial system and economy}

In order to estimate the impact on the macroeconomic and financial variables of interest associated with the ECB's policy intervention, we run two simulations of the underlying empirical model (in line with the procedures proposed in Lenza et al., 2010). These 
simulations differ solely with respect to assumptions concerning the ECB's non-standard policy measures.

First, we conduct a 'policy scenario', in which the underlying empirical model is simulated conditional on the observed path of Eurosystem intermediation. We can characterise this exercise as the policy scenario since the observed path of central bank intermediation embodies the impact of the ECB's non-standard measures. Second, we conduct a 'no policy scenario', simulating the model conditional on the path of Eurosystem intermediation that would have occurred in the absence of the introduction of policy measures (i.e., by subtracting the policy shock estimated in step 1 above from the observed series).

The difference between these two simulations captures the evolution of macroeconomic and financial variables predicted by the underlying model associated with the ECB's nonstandard measures. By conducting simulations that are common in all other respects, we can (loosely) characterise this difference between the simulations as a sort of impulse response' of the economy to the shocks underlying the ECB's policy intervention. 


\section{Results}

With the elements of the model established, we now present the main results of our exercises.

Figure 3 shows the observed and counterfactual paths for the level of central bank intermediation. In essence, it shows what we would have expected to happen during the 2008-09 recession (in which financial stress played a key role) on the basis of experience during the 1999-2004 cycle (which can be characterized as 'normal', with no exceptional financial stress).

$$
<\text { insert Figure } 3>>
$$

Pre-crisis regularities would have implied a decline in central bank intermediation, reflecting the normal pro-cyclicality of lending (and thus financial intermediation more broadly, including that across the ECB balance sheet. In particular, as the economy turned down, money and credit would have been expected to contract, and required reserves - a key determinant of central bank intermediation in normal times - would fall, in line with shrinking bank balance sheets.) But in fact central bank intermediation rose substantially during the crisis, as the ECB implemented its non-standard measures to replace the dysfunctional interbank market. The difference between the two paths shown in Figure 3 is thus one characterisation of the size of the ECB's intervention, the implications of which are traced through in our subsequent analysis.

What were the developments in the broader financial system and economy associated with this policy intervention? Figure 4 shows the difference between the policy and non-policy simulations for wholesale funding after July 2007. Notwithstanding the substitution of central bank intermediation for private intermediation that characterises the post-Lehman period, our results suggest that, as a result of the ECB's non-standard measures, the overall level of wholesale funding was higher than would have been anticipated on the basis of pre-crisis regularities.

$$
<\text { insert Figure } 4>>
$$

We offer two reasons for this outturn. First, relative to what our model predicts would have happened in their absence, the ECB's actions helped to sustain the economy as a whole and the level of financial activity. This buoyed level of real and financial activity is reflected in all variables, including that of wholesale funding. Second (and more 
importantly), the ECB's provision of central bank intermediation offered a backstop to banks: knowing that they would be able to make recourse to the ECB in the event of shortterm financing needs, some banks may have been more willing to make interbank loans than would have otherwise been the case, rather than simply hoard the available liquidity. This latter interpretation is supported by Figure 5, which shows that bank lending to both other banks and other participants in the wholesale money markets was supported by the ECB's measures.

$$
<\text { insert Figure } 5>>
$$

By offering a substitute for private interbank transactions in the form of central bank intermediation, the ECB may have helped to support those transactions. Interestingly, Figure 5 suggests that this effect was most important in the immediate aftermath of Lehman's failure, in the last quarter of 2008 and first quarter of 2009. From that point on, the positive impact of the ECB's non-standard measures on interbank lending appears to diminish. As we argued in Giannone et al. (2011b), the generosity of the ECB's facilities (especially after the introduction of one-year LTROs in June 2009) may have deterred private intermediation and bred a dependence of banks on the ECB facilities. It is interesting to note that MFI loans to other parts of the euro area financial sector (which importantly do not have direct access to the ECB facility) demonstrated a different pattern: little impact of ECB non-standard measures in the immediate aftermath of Lehman's failure, but a rising path thereafter. ${ }^{16}$ The different sectoral paths shown in Figure 5 thus support the view that access to ECB facilities was important.

Reassuringly, Figure 6 demonstrates that the ECB's provision of central bank intermediation and support for wholesale market activity described above may have also helped to sustain the flow of loans to the domestic private sector, as intended. More specifically, our model framework implies that, two years after Lehman's failure, the level of bank loans to NFCs was $6 \%$ higher than would have been expected on the basis of precrisis regularities in the data. This is a substantial impact. It holds true for both short-term loans (typically used for working capital) and long-term loans (financing capital projects).

$$
<\text { insert Figure } 6>>
$$

16 Note that ICPFs and OFIs represent a much smaller segment of the euro wholesale money market than MFIs and MMFs. Figure 5 shows percentage differences and the relative sizes of the segments need to be kept in mind in considering the chart's implications for the overall level of wholesale market activity. 
The impact on bank loans to the household sector is more modest (amounting to $1.5 \%$ on short-term loans (largely for consumption) and less than 1\% on long-term loans (typically mortgages)), but nonetheless in the right direction. While of course not preventing an overall moderation of credit expansion to the private sector, our analysis suggests that the ECB's measures have been reasonably effective in insulating the flow of loans to the real economy from the obvious post-Lehman dislocations in the financial sector in general, and the wholesale money market in particular.

This is reflected in Figures 7 and 8, which employ the macroeconomic block of our empirical model to estimate the impact of the ECB measures on the level of economic activity and the labour market respectively.

$$
<\text { insert Figure } 7 \text { and } 8>>
$$

Figure 7 suggests that, two years after Lehman's failure, the level of euro area industrial production was $2 \%$ higher than would have been the case in the absence of the ECB's non-standard measures, while Figure 8 points to a lower unemployment rate of around 0.6 percentage points.

This are meaningful, albeit modest, stabilising effects: they mitigate but do not offset the overall fall in macroeconomic activity associated with the onset of the 2008-09 'Great Recession'. But it should be recognised that these estimates probably represent a lower bound on the true impact. Our no policy counterfactual assumes that the financial sector continues to behave in line with the pre-crisis regularities embodied in our empirical model. But many observers have argued that a 1930s-style financial collapse would have ensued if the ECB had not acted promptly and decisively in introducing its non-standard measures.

Figures 3 to 8 provide only information on the expected effect of policy intervention, which can be seen as an estimate of the economic relevance of policy. In order to assess its statistical significance, we complement this information by providing also a probabilistic assessment. To this end we examine the entire probability distribution of the outcomes implied by the counterfactual exercises. In order to compute such distribution we draw the model's parameters from their posterior and for each draw of the parameters we generate counterfactual draws from the predictive density implied by the conditional forecasts. ${ }^{17}$

\footnotetext{
${ }^{17}$ Following Banbura et al. (2012) conditional forecasts are obtained by casting the model in its state space form. Hence, the conditional forecasts can be drawn using the simulation smoother of Carter and Kohn (1994).
} 
Table 2 reports the probability that the outlook for each given variable would have been worse in absence of policy. Precisely, for each variable, we report the probability that the level of the variable is higher in the policy scenario relative to the no-policy scenario. For unemployment we report (for obvious reasons) the probability that its level is lower in the policy relative to the no-policy scenario. The higher the probability, the higher the likelihood that the macroeconomic and financial conditions would have been more adverse in absence of the non-standard ECB policy measures. We consider 4 periods: January 2008, January 2009, January 2010 and January 2011.

Table 2: A probabilistic assessment of the effects of non-standard policy

\begin{tabular}{|l|c|c|c|c|}
\hline Variable & Jan-08 & Jan-09 & Jan-10 & Jan-11 \\
\hline Industrial Production & 0.53 & 0.67 & 0.72 & 0.66 \\
\hline Unemployment & 0.45 & 0.74 & 0.86 & 0.85 \\
\hline Loans to MFIs & 0.54 & 0.64 & 0.61 & 0.55 \\
\hline Loans to OFIs+ICPFs+Non-resident+MMF & 0.59 & 0.55 & 0.60 & 0.63 \\
\hline Short-term loans to NFCs & 0.44 & 0.73 & 0.86 & 0.82 \\
\hline Long-term loans to NFCs & 0.45 & 0.69 & 0.83 & 0.82 \\
\hline Short-term loans to HHs & 0.52 & 0.63 & 0.69 & 0.64 \\
\hline Long-term loans to HHs & 0.55 & 0.70 & 0.73 & 0.66 \\
\hline Eurosystem liquidity & 0.58 & 0.95 & 0.88 & 0.52 \\
\hline Wholesale funding & 0.56 & 0.56 & 0.55 & 0.58 \\
\hline
\end{tabular}

Note: The acronyms in the table are: NFCs (Non-financial corporations), HHs (households), MFIs (Monetary and financial institutions), OFIs (Other financial institutions), ICPFs (Insurance companies and pension funds), MMFs Money market funds). Values refer to the probability of observing a positive impact associated to Eurosystem policy. In red, we highlighted values smaller than 0.5 , i.e. variables for which more than half the distribution of the impacts lie below the zero line while in light blue we highlight variables for which more than $70 \%$ of the distribution lies above the zero line.

Table 2 highlights the very high probability our model attaches to an increase in Eurosytem liquidity provision (and thus central bank intermediation) in the policy relative to the nopolicy scenario. In particular, almost all our simulations reflect the unprecedented nature of the injection of central bank liquidity in the aftermath of Lehman's collapse. As regards the other variables in our model, Table 2 confirms that, in general, the impact of Eurosystem policy is more likely to be positive than negative, with the bulk of their impact coming after the Lehman bankruptcy. Our results seem quite robust for two key variables: unemployment and loans to non-financial corporations. At the same time, with regard to the evolution of wholesale funding (and lending) and, albeit to a lesser extent, loans to households, while the effects are more likely to be in the expected positive direction, the uncertainty around the estimates is relatively large. 


\section{Caveats}

The interpretation of our results impinges on the assumption that the VAR coefficients have remained stable in the post-Lehman sample. However, it is plausible that agents' behaviour was affected by the non-standard monetary policy. A change in policy, if anticipated and immediately incorporated in agents' beliefs, may change the way the private sector react to economic information, thereby causing instability in the parameters of the model. In other words, our methodology is not immune from the Lucas' (1976) critique.

However, the Lucas' effect is likely to have been small in the aftermath of the Lehman collapse. The ensuing recession was large and unexpected by both policy-makers and the private sector. Moreover, it is unlikely that agents immediately understood the impact of the non-standard policies, since such operations were novel in nature and their impact uncertain. Contrary to quantitative easing measures, which had been implemented earlier in Japan and were discussed extensively in both academic and policy circles, the ECB's non-standard measures were unprecedented. At the same time, we acknowledge that, as experience of the non-standard measures accumulated and despite the high level of uncertainty that continued to surround them, economic agents may have learned about the new regime. It is not clear in which direction this effect may have biased our results. However, since our exercise assesses the effects of policy intervention in the interbank system in normal times, it captures only one aspect of ECB intervention and therefore is likely to under-estimate the effect of the ensemble of ECB action. Over that period the ECB has not only injected liquidity but has also stabilized expectations and hence prevented contagion of the financial turmoil. 


\section{Concluding remarks}

The analysis presented in this paper confirms and extends the earlier results shown in Lenza et al. (2010) and Giannone et al. (2011). We find that the introduction of the ECB's non-standard measures supported market functioning and the transmission of monetary policy to the real economy, thereby bolstering macroeconomic activity and employment in a modest but significant way.

An important innovation in the present analysis is the use of a much richer database than in the past, which offers a much more comprehensive coverage of euro area banks' balance sheets. Crucially, the aggregate MFI balance sheet data that we employ allows us to identify the nature and magnitude and intra-financial sector financial flows. In particular, we can distinguish between private intermediation of interbank transactions in the money market and central bank intermediation of bank-to-bank transactions across the Eurosystem balance sheet. Since we argue that substitution of the latter for the former is a key channel of transmission for the ECB's non-standard monetary policy measures through the financial system to the real economy, developing an empirical framework that allows investigation and estimation of the behavioural interactions among banks and the central bank is an important step forward in our research agenda.

Using this framework, we construct a new estimate of the policy shock stemming from the ECB's non-standard measures, which reflects how the central bank has both substituted for and supported interbank transactions. Simulations of our empirical model deriving from our estimate of the policy shocks demonstrate how the ECB's intervention in the money market has had a significant effect on credit markets more widely and indirectly on economic activity in the euro area. 


\section{References}

Adrian, T. and Shin, H-S. (2010a). 'Financial intermediaries and monetary economics', in B.M. Friedman and M. Woodford (eds.) Handbook of Monetary Economics, pp. 601-650, Elsevier.

Adrian, T. and Shin, H-S. (2010b). 'Liquidity and leverage', Journal of Financial Intermediation vol. 19(3), pp. 418-437.

Banbura, M., Giannone, D. and Lenza, M. (2012). 'Conditional forecasting with large vector autoregressions: an application to the euro area', ECB mimeo.

Banbura, M., Giannone, D. and Reichlin, L. (2010). 'Large bayesian VARs', Journal of Applied Econometrics, vol. 25, pp. 71-92.

Brunnermeier, M.K. and Pedersen, L.H. (2009). 'Market liquidity and funding liquidity', Review of Financial Studies, vol. 22(6), pp. 2201-2238.

Carter, C.K. and R. Kohn (1994). "On Gibbs sampling for state space models". Biometrika, vol. 81(3), pp. 541-553.

Chari, V.V., Christiano, L. and Kehoe, P.J. (2008). 'Facts and myths about the financial crisis of 2008, FRB Minneapolis working paper no. 666.

De Mol, C., Giannone, D. and Reichlin, L. (2008). 'Forecasting using a large number of predictors: Is bayesian regression a valid alternative to principal components?', Journal of Econometrics, vol. 146(2), pp. 318-328.

Doan, T., Litterman, R. and Sims, C. A. (1984). 'Forecasting and conditional projection using realistic prior distributions', Econometric Reviews, vol. 3, pp. 1-100.

Durre, A. and Pill, H. (2010). 'Non-standard monetary policy measures, monetary financing and the price level', ECB mimeo.

Durre, A. and Pill, H. (2012). 'Central bank balance sheets as monetary policy tools', BIS Papers, forthcoming.

Fahr, S., Motto, R., Rostagno, M., Smets, F. and Tristani, O. (2010). 'Lessons for monetary policy strategies from the recent past' in M. Jarociński, F. Smets and C. Thimann (eds.) Approaches to monetary policy revisited: Lessons from the crisis, pp. 26-66, Frankfurt: European Central Bank.

Fama, E.F. (1970). 'Efficient capital markets', Journal of Finance, vol. 25(2), pp. 383-417.

Giannone, D., Lenza, M. and Primiceri, G. (2012). 'Prior selection for vector autoregressions', CEPR discussion paper no. 8755.

Giannone, D., Lenza, M., Pill, H. and Reichlin, L. (2011a). 'Non-standard monetary policy measures and monetary developments', in J. Chadha and S. Holly (eds.) Interest rates, prices and liquidity, pp. 195-221, Cambridge University Press.

Giannone, D., Lenza, M., Pill, H. and Reichlin, L. (2011b). 'Monetary policy and financial stability', in S. Claessens, D.D. Evanoff, G.G. Kaufman and L.E. Kodres (eds.) Macroprudential regulatory policies: The new road to financial stability? pp. 103-120, World Scientific: Studies in International Economics 17. 
Giannone, D., Lenza, M., Pill, H. and Reichlin, L. (2012). 'Bank balance sheets in the financial crisis, ECB mimeo.

Gorton, G.B. and Metrick, A. (2012). 'Securitized banking and the run on repo', Journal of Financial Economics, vol. 104(3), pp. 425-451.

Heider, F., Hoerova, M. and Holthausen, C. (2009). 'Liquidity hoarding and interbank market spreads: the role of counterparty risk', ECB working paper no. 1126.

Joyce, M., Lasaosa, A., Tong, M. and Stevens, I. (2010). 'The financial market impact of quantitative easing', Bank of England working paper no. 393.

Lenza, M., Pill, H. and Reichlin, L. (2010). 'Monetary policy in exceptional times', Economic Policy, vol. 62, pp. 295-339.

Litterman, R. B. (1980). 'A bayesian procedure for forecasting with vector autoregressions', Massachusetts Institute of Technology working paper.

Lucas, R.E. (1976). "Econometric policy evaluation: A critique". Carnegie-Rochester Series on Public Policy, vol. 1, pp. 19-46.

Shin, H-S. and Shin, K. (2011). 'Procyclicality and monetary aggregates', NBER working paper no. 16836.

Stiglitz, J.E., and Weiss, A. (1981). 'Credit rationing in markets with imperfect information', American Economic Review vol. 71(3), pp. 393-410.

Trichet, J-C. (2009). “The ECB's enhanced credit support," address at the University of Munich annual symposium, http://www.ecb.europa.eu/press/key/date/2009/html/sp090713.en.html.

Walsh, C. (1982). 'Asset substitutability and monetary policy', Journal of Monetary Economics, vol. 9(2), pp. 59-71. 
Fig. 1: Sources of bank funding in the euro area

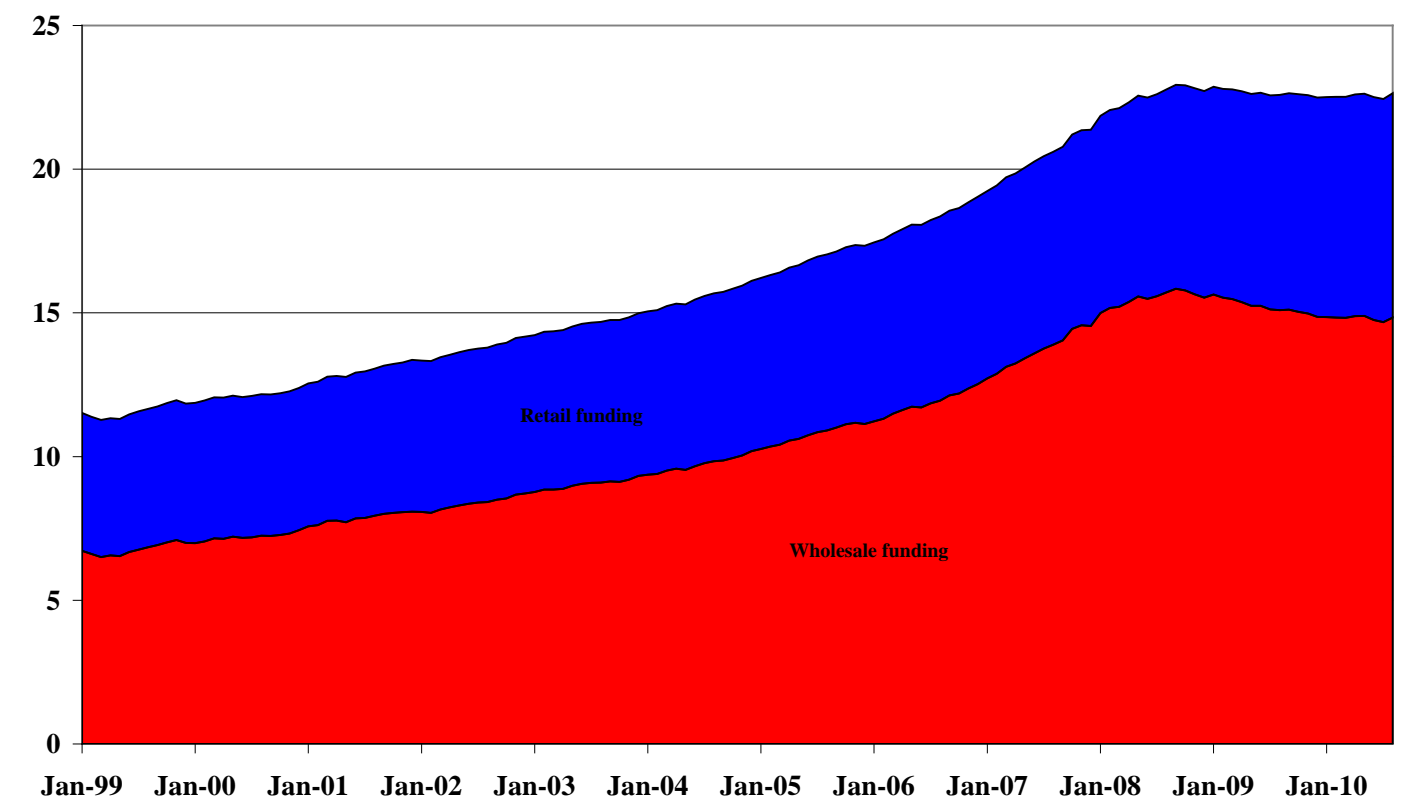

Note: The figure reports data on the amount of retail (blue area) and wholesale (red area) funding in the euro area Figures are expressed in terms of thousands of billions 
Fig. 2: Central bank intermediation

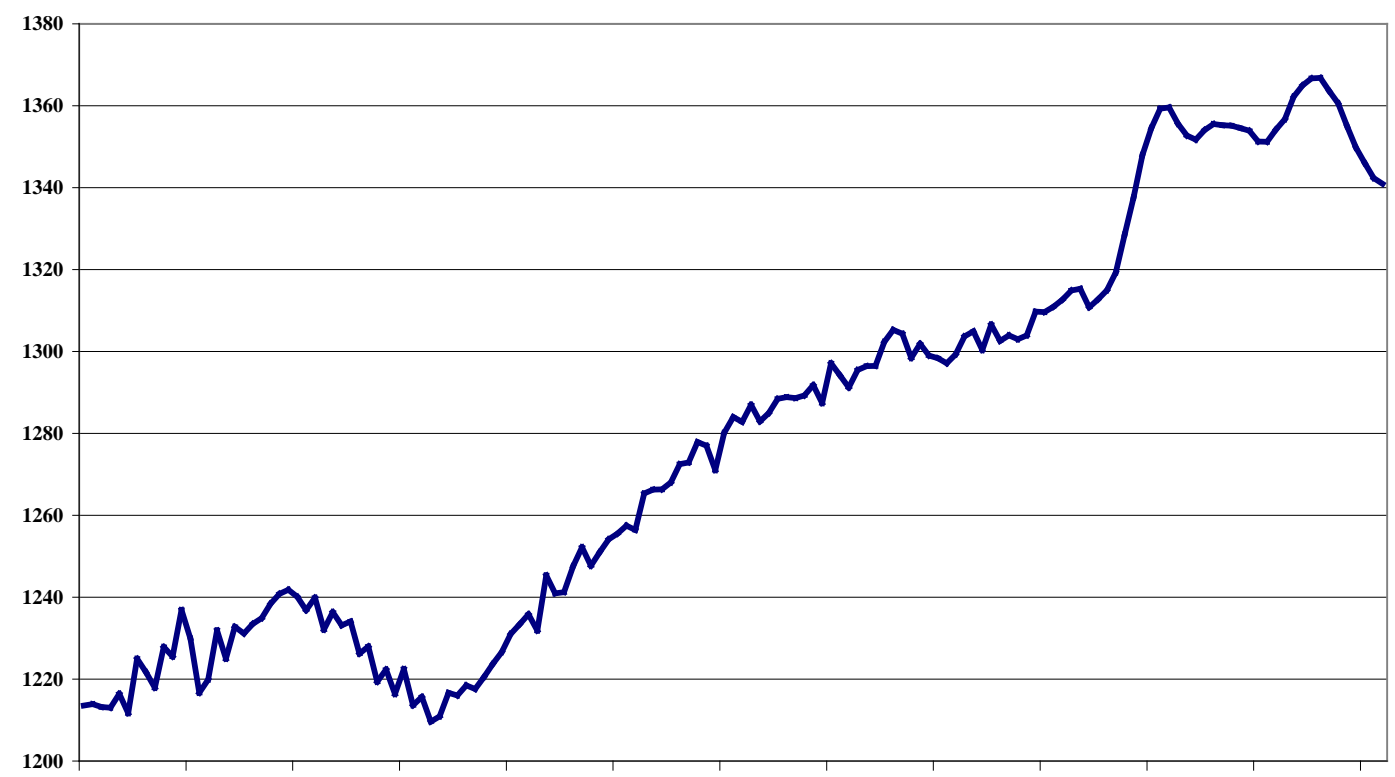

Jan-99 Jan-00 Jan-01 Jan-02 Jan-03 Jan-04 Jan-05 Jan-06 Jan-07 Jan-08 Jan-09 Jan-10 Jan-11

as a percentage of MFI liabilities

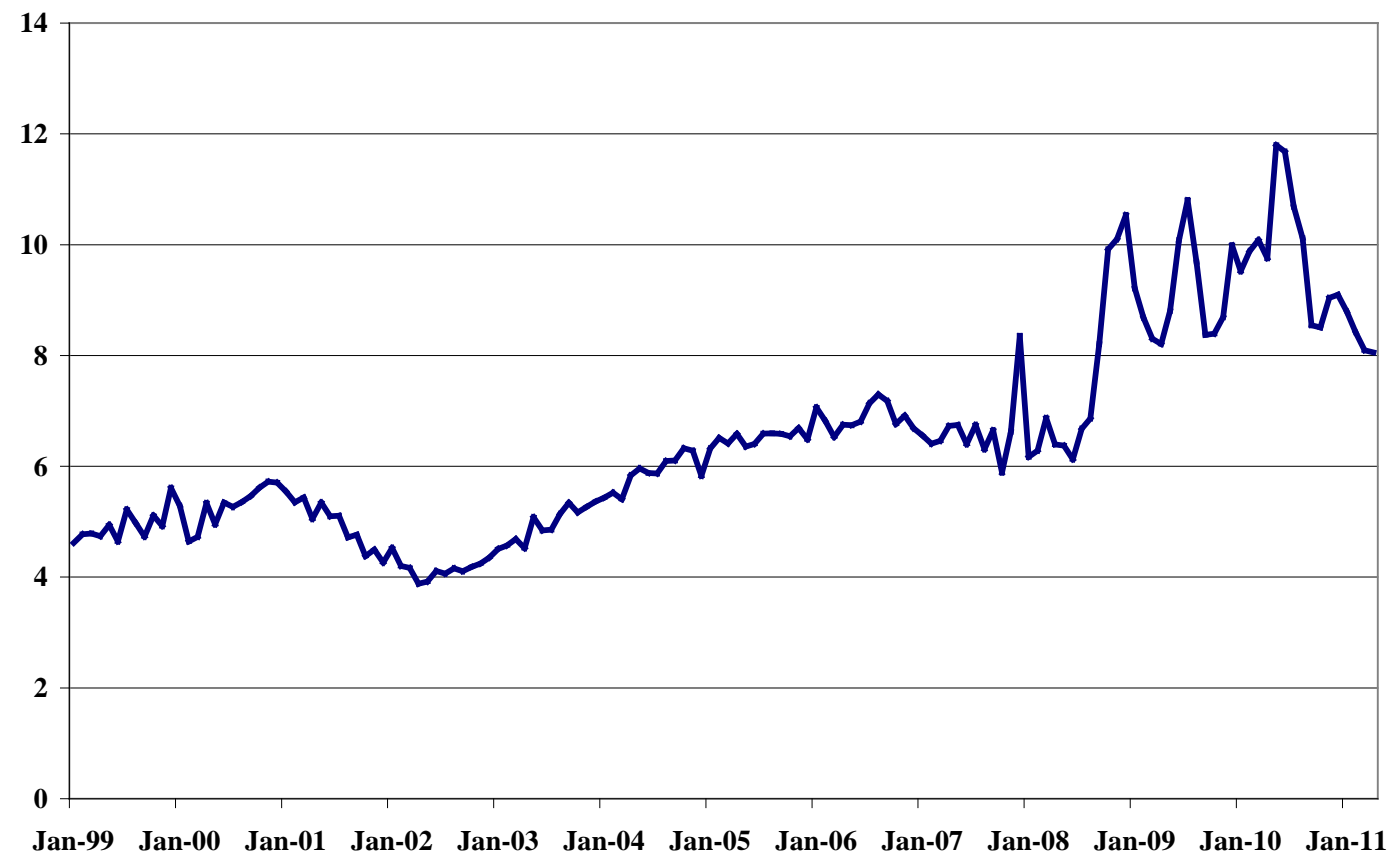

Note: The upper panel reports the logarithm of Eurosystem intermediation expressed in terms of EUR millions The lower panel reports the percentage of Eusosystem intermediation in total interbank liabilities 
Fig. 3: Policy shock - Observed and counterfactual levels of central bank intermediation

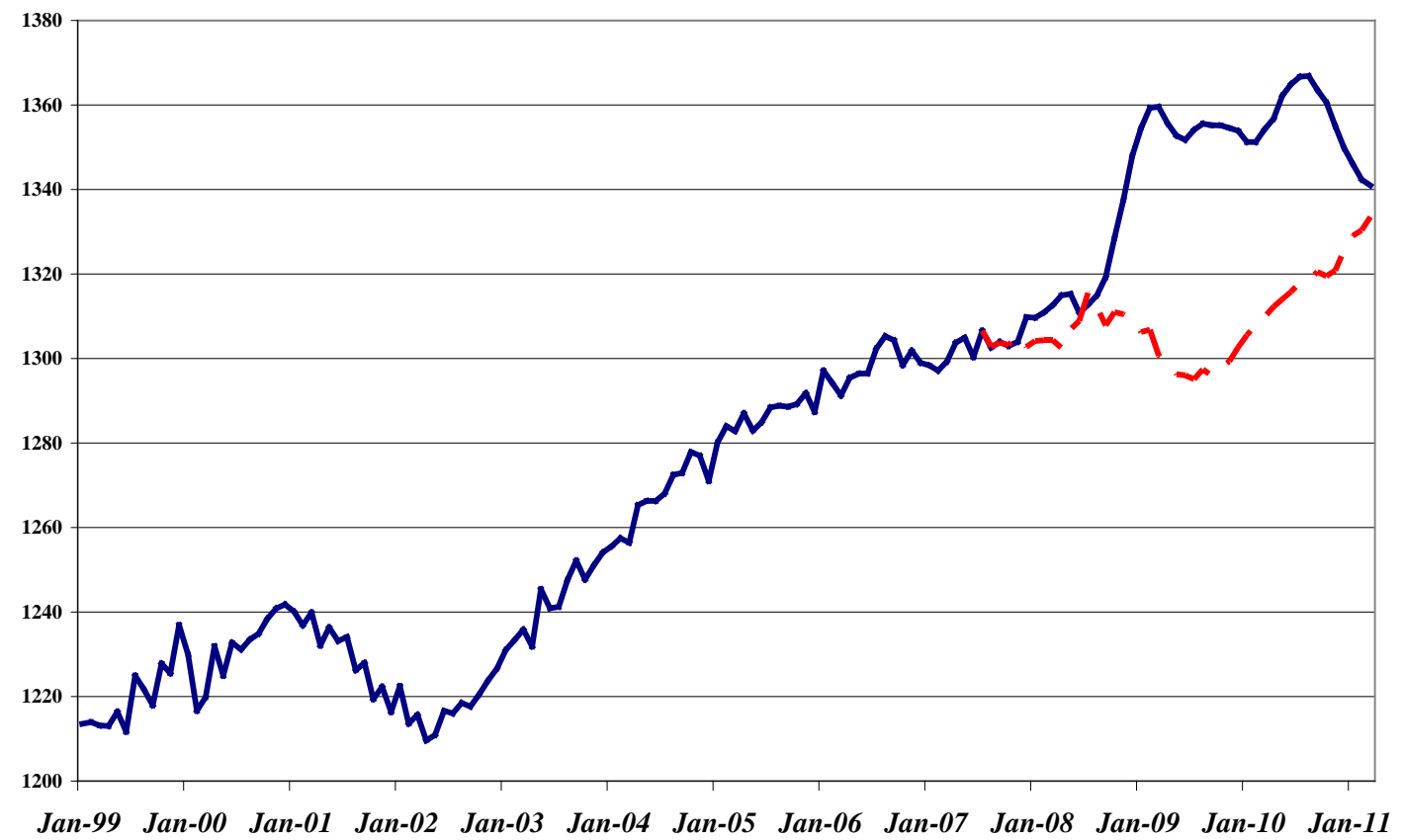

Note: The figure reports the log of Eurosystem intermediation expressed in terms of EUR millions in the policy scenario (blue solid line) and in the no-policy scenario (red dashed line)

Fig. 4: Difference between policy and non-policy scenarios for wholesale funding

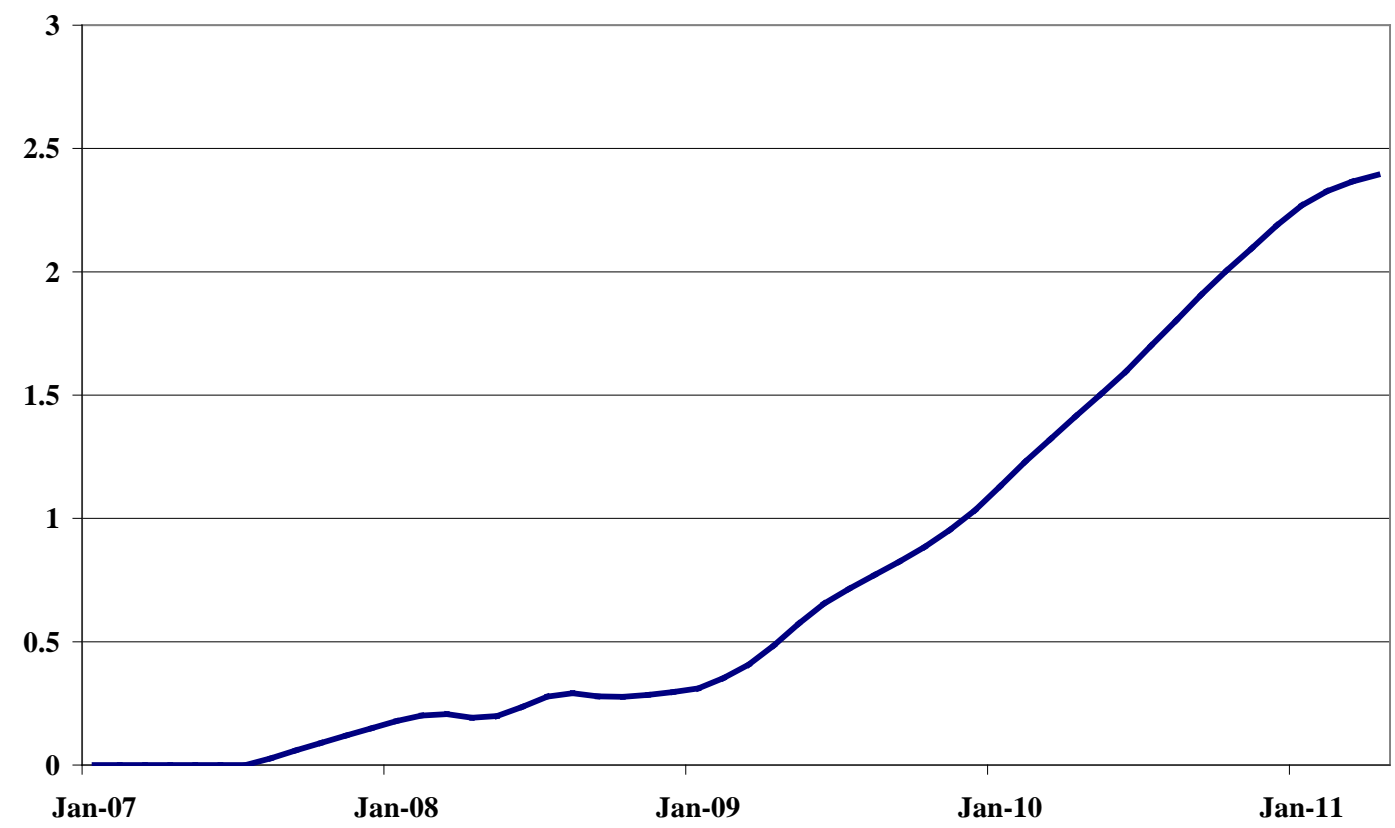

Note: The figure reports the difference in the logarithm of wholesale funding in the policy and in the no-policy scenarios Positive figures indicate that the value of the variable in the policy scenario is higher than in the no-policy scenario 
Fig. 5: Difference between policy and non-policy scenarios for loans to financial sector

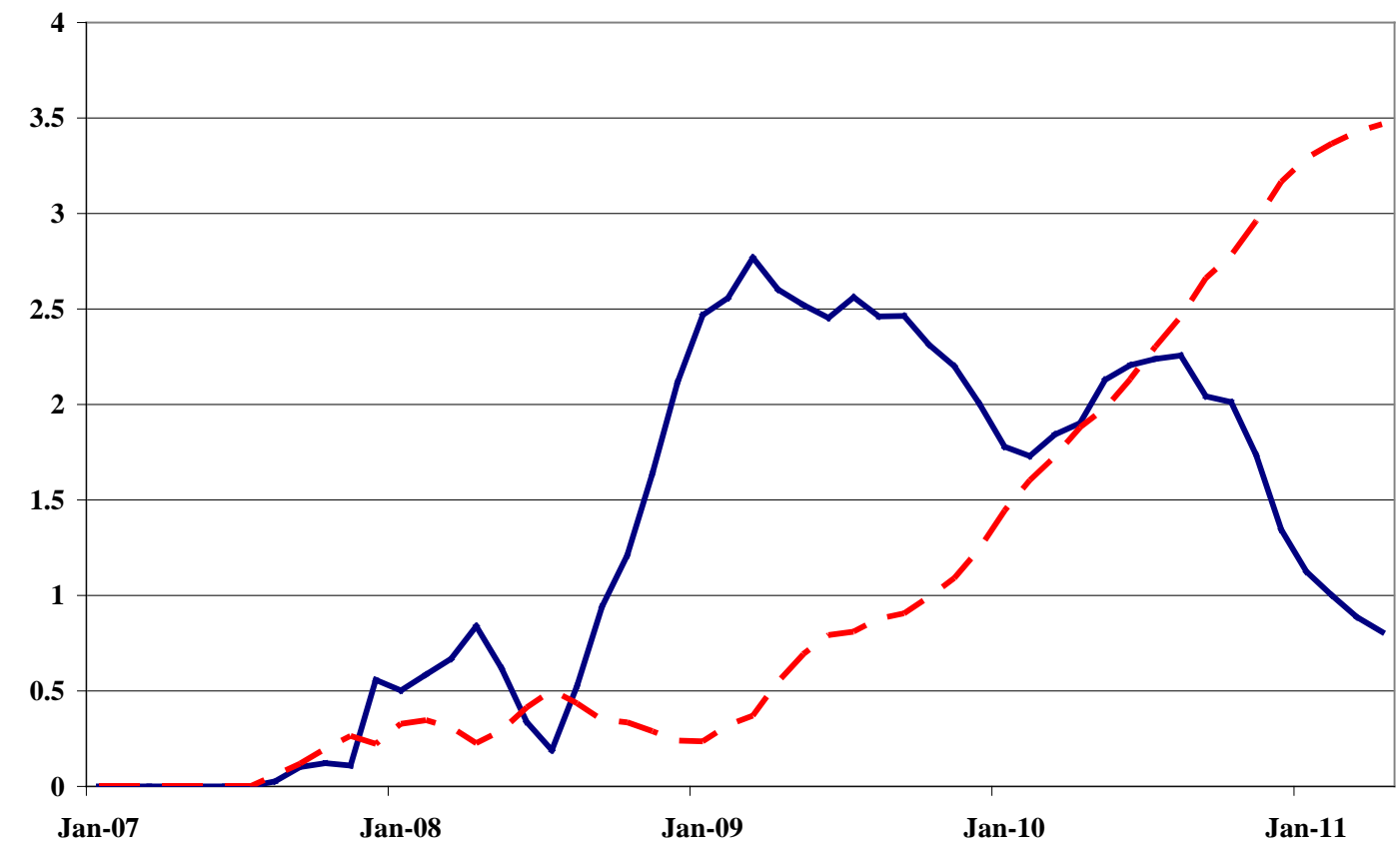

Note: The figure reports (i) the difference in the logarithms of loans to MFIs (blue solid line) and (ii) the difference in the logarithms of loans to OFIs, ICPFs, and MMFs in the policy and in the no-policy scenarios Positive figures indicate that the value of the variable in the policy scenario is higher than in the no-policy scenario

Fig. 6: Difference between policy and non-policy scenarios for loans to private sector

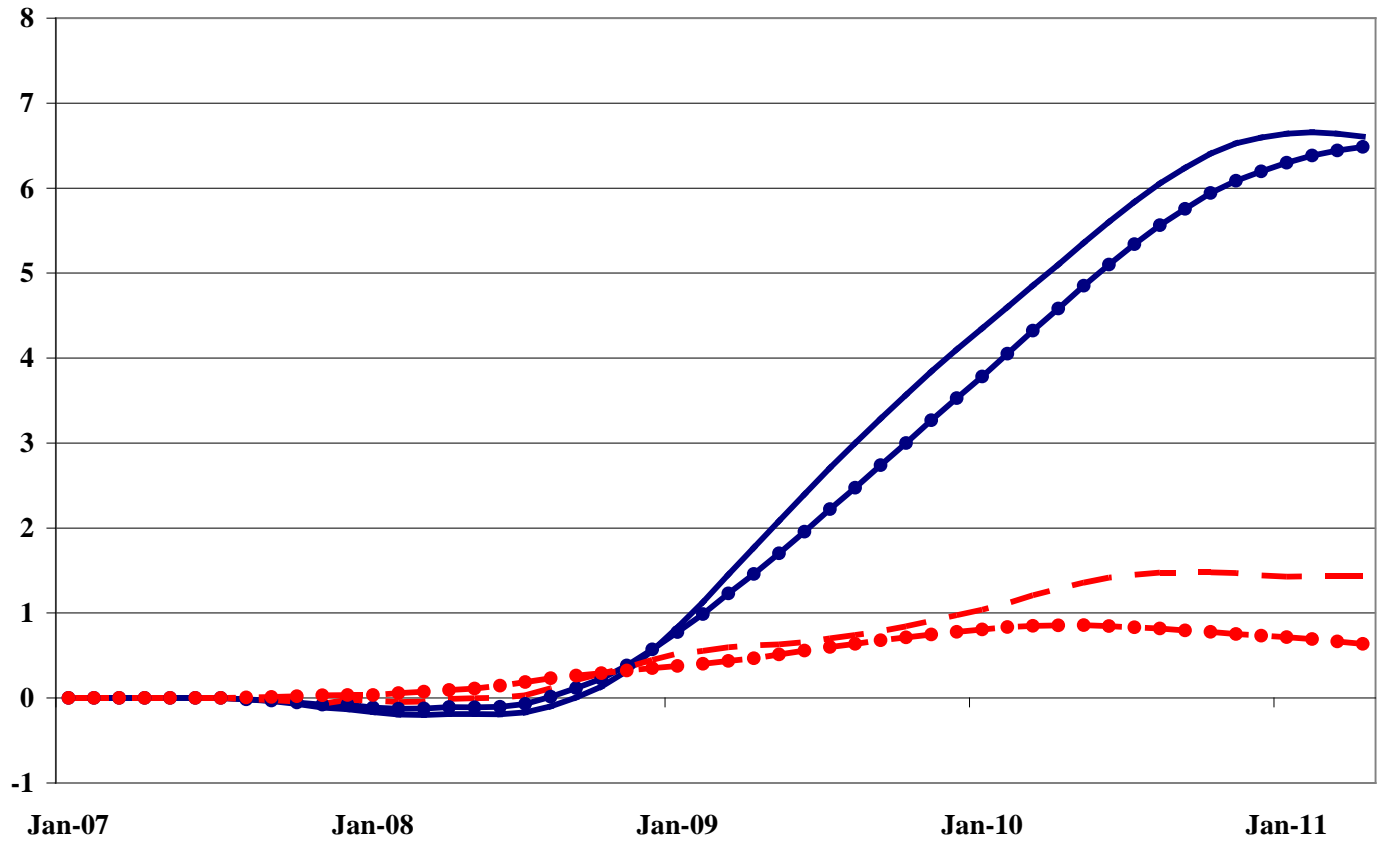

Note: The figure reports (i) the difference in the logarithms of short-term loans to NFCs (blue solid line), (ii) the difference in the logarithms of long-term loans to NFCs (blue solid line with circles), (iii) the difference in the logarithms of short-term loans to Households (red dashed line) and (iv) the difference in the logarithms of long-term loans to Households (red dashed line with circles) in the policy and in the no-policy scenarios Positive figures indicate that the value of the variable in the policy scenario is higher than in the no-policy scenario 
Fig. 7: Difference between policy and non-policy scenarios for level of industrial production

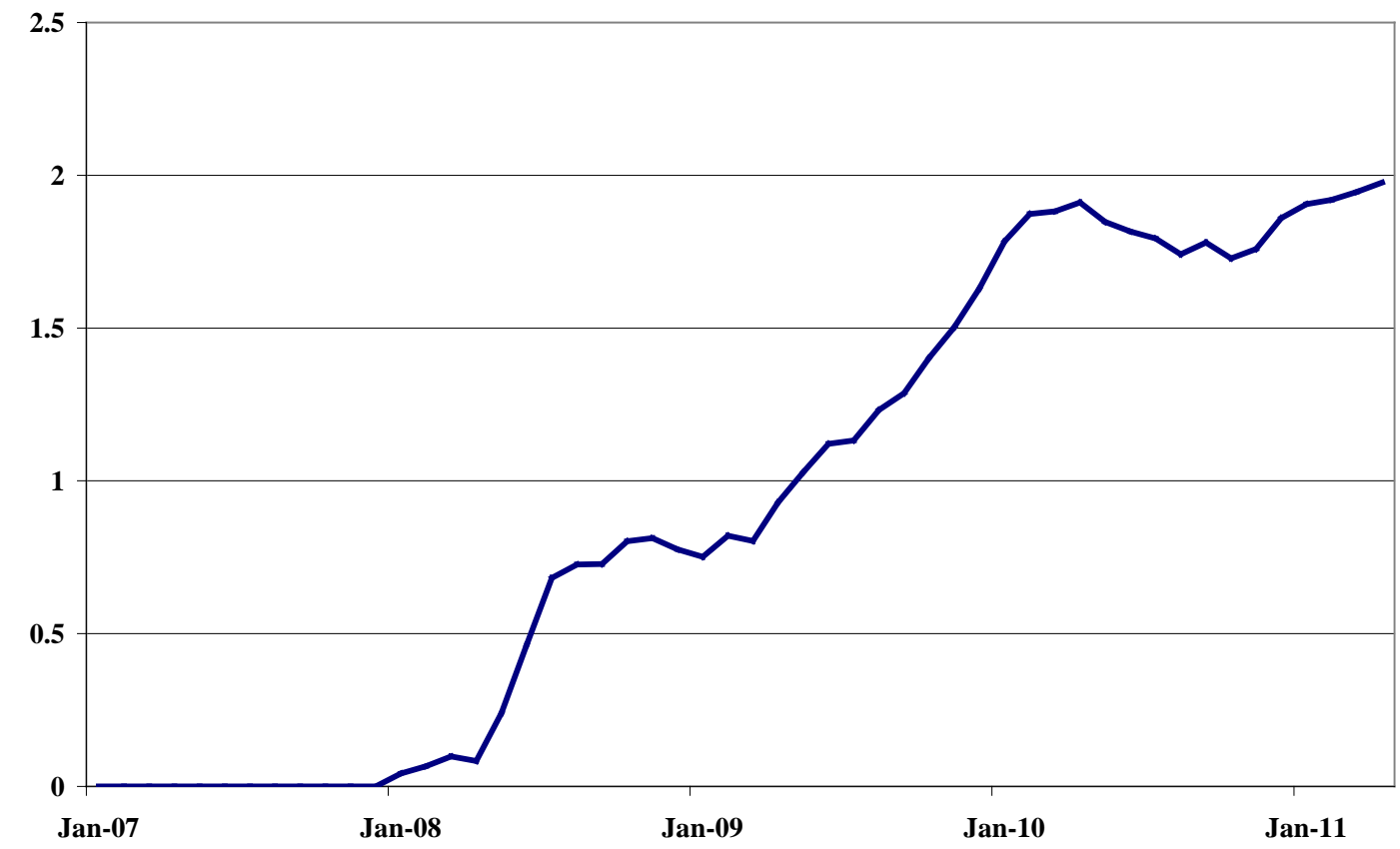

Note: The figure reports the difference in the logarithm of industrial production in the policy and in the no-policy scenarios Positive figures indicate that the value of the variable in the policy scenario is higher than in the no-policy scenario

Fig. 8: Difference between policy and non-policy scenarios for level of unemployment

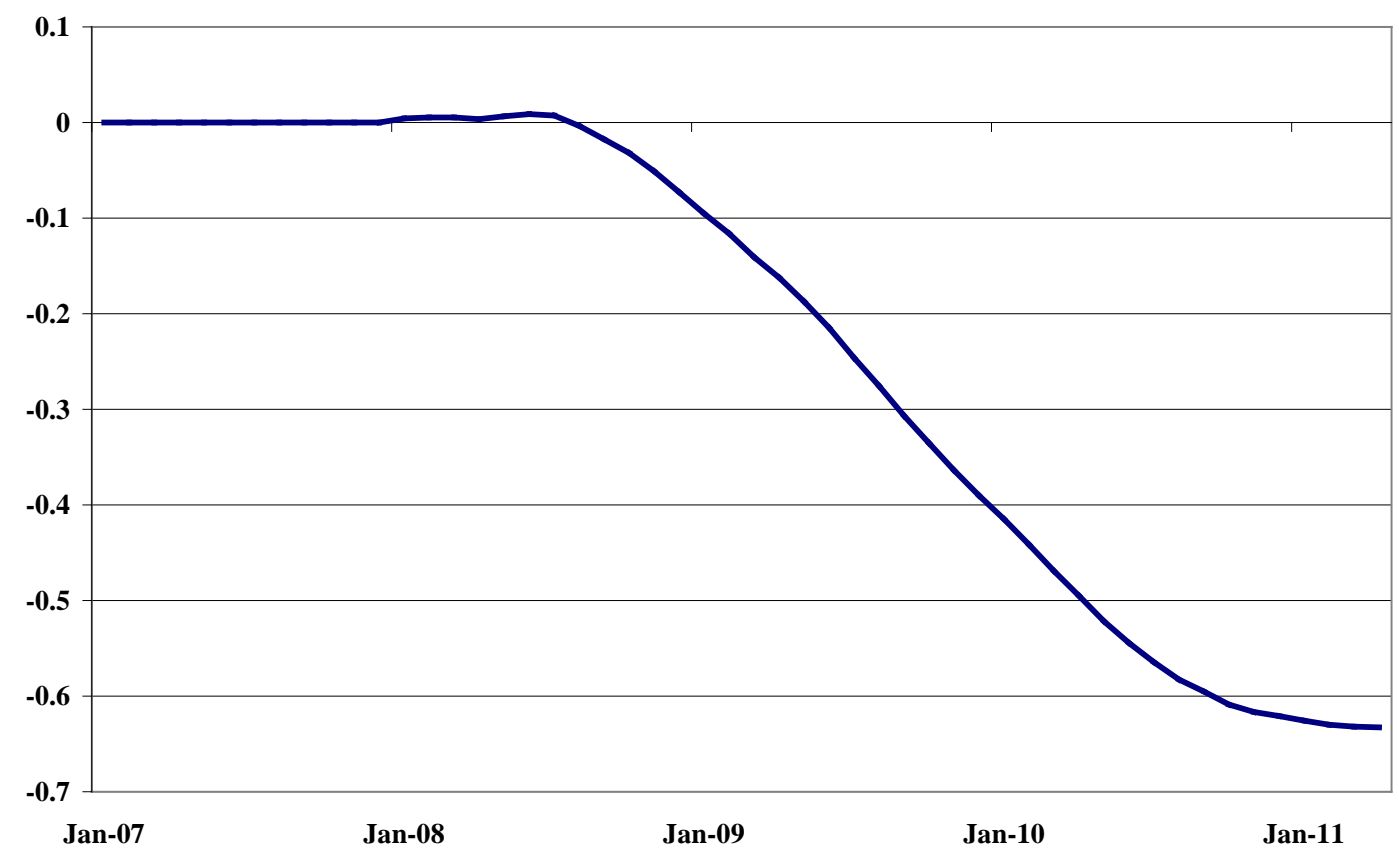

Note: The figure reports the difference in the levels of the unemployment rate in the policy and in the no-policy scenarios Positive figures indicate that the value of the variable in the policy scenario is higher than in the no-policy scenario Figures are expressed in percentage points 


\section{Appendix: Database and transformations}

\begin{tabular}{|c|c|c|}
\hline & Variables & Transformation \\
\hline \multirow{6}{*}{$\begin{array}{l}\text { Macroeconomic } \\
\text { environment }\end{array}$} & Industrial production & Log-levels \\
\hline & Harmonized Index of Consumer Prices (HICP) & Log-levels \\
\hline & Unemployment & Levels \\
\hline & Producer Price Index (PPI) & Log-levels \\
\hline & US industrial production & Log-levels \\
\hline & US Consumer prices & Log-levels \\
\hline \multirow[t]{9}{*}{ Interest rates } & Federal Funds rate & Levels \\
\hline & Euribor three-months & Levels \\
\hline & Lending rate, NFCs, short-term credit & Levels \\
\hline & Lending rate, $\mathrm{HHs}$, consumer loans & Levels \\
\hline & Lending rate, $\mathrm{HHs}$, loans for house purchases & Levels \\
\hline & Lending rate, NFCs, long-term credit & Levels \\
\hline & Bond rates, two years maturity & Levels \\
\hline & Bond rates, five years maturity & Levels \\
\hline & Bond rates, ten years maturity & Levels \\
\hline \multirow[t]{2}{*}{ Stock Prices } & Stock prices, Dow Jones Eurostoxx & Log-levels \\
\hline & Stock prices, banks & Log-levels \\
\hline \multirow[t]{26}{*}{ Banks Balance sheet } & Short-term loans to NFCs & Log-levels \\
\hline & Long-term loans to NFCs & Log-levels \\
\hline & Short-term loans to HHs & Log-levels \\
\hline & Long-term loans to HHs & Log-levels \\
\hline & Debt securities non-MFIs & Log-levels \\
\hline & Government, loans and debt securities & Log-levels \\
\hline & Loans to OFIs+ICPFs+Non-resident+MMF & Log-levels \\
\hline & Loans to MFIs & Log-levels \\
\hline & Debt securities MFIs+MMfs & Log-levels \\
\hline & Debt securities Non-resident & Log-levels \\
\hline & Equity & Log-levels \\
\hline & Fixed and other assets & Log-levels \\
\hline & Short-term deposits, NFCs and HHs & Log-levels \\
\hline & Long-term deposits, NFCs and HHs & Log-levels \\
\hline & Short-term deposits, OFIs, ICPFs and MMFs & Log-levels \\
\hline & Long-term deposits, OFIs, ICPFs and MMFs & Log-levels \\
\hline & Short-term deposits, government & Log-levels \\
\hline & Long-term deposits, government & Log-levels \\
\hline & Deposits, non-residents & Log-levels \\
\hline & Short-term liabilities of MFIs excluding Eurosystem & Log-levels \\
\hline & Long-term liabilities of MFIs excluding Eurosystem & Log-levels \\
\hline & Liabilities versus Eurosystem & Log-levels \\
\hline & Short-term debt securities & Log-levels \\
\hline & Long-term debt securities & Log-levels \\
\hline & Remaining liabilities & Log-levels \\
\hline & Capital & Log-levels \\
\hline
\end{tabular}

Note: The acronyms in the table are: NFCs (Non-financial corporations), HHs (households), MFIs (Monetary and financial institutions), OFIs (Other financial institutions), ICPFs (Insurance companies and pension funds), MMFs (Money market funds) The sample ranges from January 1999 to April 2011 (monthly data, 148 observations) 